\title{
TAEVAKEHAD EESTI TAIMEPÄRIMUSES
}

Raivo Kalle ja Renata Sõukand

\begin{abstract}
TEESID: Käesolev artikkel analüüsib taevakehade seotust taimenimedega, taevakehade arvatavat mõju põlluharimisele ja taimekasvatusele endistel aegadel ja tänapäeval ning taevakehade ja astroloogia kajastusi taimravis. Tähega seotud nimesid on pandud viie või enama kroonlehega erivärvilistele õistaimedele, kuu(paiste)ga on nime tasandil seostatud vaid harilikku härgheina ning päikesega seostatakse enamasti kollaste kroonlehtedega õistaimi. Suur osa nimedest on tulnud kirjandusest, kusjuures Soomes on taimenimede seotus taevakehadega märkimisväärselt mitmekesisem. Taevakehadest on eestlaste taimekasvatuses ja -kasutuses olulist rolli mänginud vaid kuu, teadaolevad kokkupuutekohad on rahvusvahelise iseloomuga ja valikuliselt integreeritud algsesse pärimusse traditsiooni katkemise järel. Astroherbalism levis Eestisse alles teise levikulaine käigus, intensiivsemalt pärast Nõukogude korra lagunemist. Taimede tundmine ja kasutus kui praktiline teadmine on eestlastel olnud üldiselt eraldiseisev abstraktsest ja elukaugest tähetarkusest.
\end{abstract}

MÄRKSÕNAD: etnobotaanika, etnoastronoomia, taimenimed, astroherbalism, külvikalendrid, taevakehad

Käesoleva artikli idee sündis 2009., rahvusvahelisel astronoomia-aastal, mil tähistati ülemaailmselt astronoomia kui teaduse panust ühiskonda ja kultuuri, samuti 400 aasta möödumist esimese astronoomilise teleskoobi ehitamisest Galileo Galilei poolt. Umbes 400 aastat tagasi läksid lahku ka astronoomia ja astroloogia - teine neist muutus teadusest pigem kunstiks, mis kasutas astronoomide väljaarvutatud planeetide seise ennustamisel, ravil jm. See vahetegemine oli tähtis siiski peamiselt teadlastele, 
tavainimeste jaoks põimuvad need valdkonnad veel tänapäevalgi. Kas võib aga leida midagi ühist astronoomial ja botaanikal, kui üks uurib taevaseid ja teine maapealseid objekte? Ühendavaks lüliks ongi just uuriv inimene, kelle kogemused ühe ja teise valdkonnaga võivad mõnikord ka põimuda. Inimkultuuri ja taimede vahelisi suhteid uurib etnobotaanika ja astronoomiatki on vaadeldud läbi pärimuse prisma: näiteks paleoastronoomias (Eelsalu 1985), etnoastronoomias (Kuperjanov 2003, jm), arheoastronoomias (Kõiva 2006).

Käesolev artikkel püüab vastata küsimusele, kuidas on nii nähtavad kui silmaga nähtamatud taevakehad mõjutanud eestlaste taimedega seotud pärimust. Analüüsime taevakehade seotust taimenimedega, taevakehade arvatavat mõju põlluharimisele ja taimekasvatusele, taevakehade ja astroloogia kajastusi taimravis endistel aegadel ja tänapäeval. Esmapilgul on need teemad küllalt erinevad, et käsitleda neid iseseisvates artiklites, kuid eesti materjali vähesuse tõttu on nad koondatud ühte, läbivateks märksõnadeks taevakehad ja taimed.

\section{TAEVAKEHAD TAIMENIMEDES}

Võib väita, et taimi on Eestis nimetatud läbi aegade nende välimuse, omaduste või kasutusviiside järgi. Sama reegel kehtib Eesti seente rahvapäraste nimetuste kohta. Taimenimede kogumise, tuvastamise ja analüüsimise suure töö on ära teinud esimene eestlasest etnobotaanik Gustav Vilbaste ja siinkohal on kasutatud tema raamatus „Eesti taimenimetused“ (1993) toodud andmeid. ${ }^{1}$ Paralleelselt on kasutatud Soome taimenimede uurija Pentti Suhoneni raamatut „Suomalaiset kasvinnimet“ (1936), otsides sarnasusi kahe sugulasrahva taimenimede vahel.

Sõna täht abil moodustatud nime, nt taevatäht, tähelill, tähtlill, tähekukas, on eesti keeles saanud õistaimed, kellel on kroonlehti vähemalt viis või üle selle. ${ }^{2}$ Üle-eestiliselt kutsuti nende nimedega, samuti hommikutäheks, mets(a)täheks, nõmmetäheks valgete kroonlehtedega harilikku laanelille (Vilbaste 1993: 626). Soomlastel on selle liigi rahvapärasteks nimedeks aamutähti, iltatähti, metsätähti, mettäntähti, sammaltähti, tähtikukka, tähtikukkanen (Suhonen 1936: 375). Kuigi kultuurtaimed said enamasti oma rahvapärased nimed võõrkeelse nime tõlkest või mugandusest, on

${ }^{1}$ Taimenimede otsimiseks on kasutatud raamatu elektroonilist versiooni (Peil 1993).

${ }^{2}$ Arvestades tuvastatud taimede ohtrust ja erinevust, võib oletada, et sellise nimetusega lilleliike võis olla veelgi rohkem. 


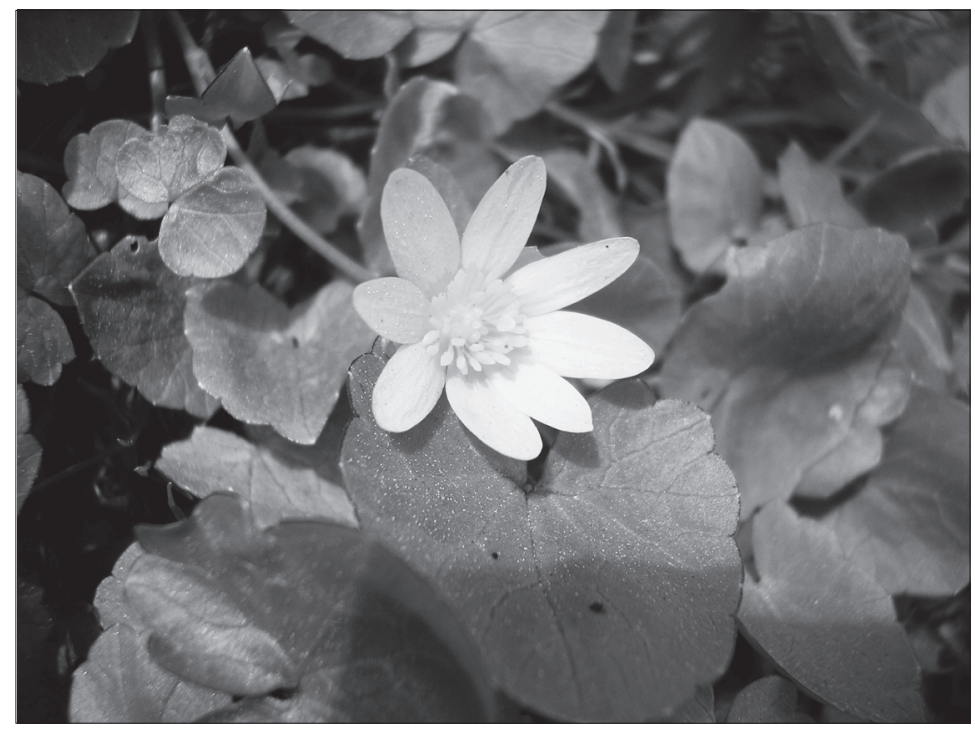

Kuldtäht ja taevatäht on rahvapärasteks nimedeks kanakoolmel. Pilt: Renata Sõukand ja Raivo Kalle.

lokaalselt selliste nimedega kutsutud ka mõningaid valgest lilla-punase toonini varieeruvaid kultuurtaimi, nagu pajulehine aster ${ }^{3}$ (Vilbaste: 181), hiina aedaster (samas: 213) ja harilik kurekell (samas: 166). Pärismaistest taimedest on näiteks kutsutud Kuusalus tähelilleks punaseõielist punast pusurohtu (samas: 584) ja Saardes taevatäheks kollaste kroonlehtedega kollast ülast (samas: 156). Kollaseõielist harilikku kanakoolet on kuldtäheks ja taevatäheks kutsutud samuti Saardes, aga ka Vigalas ning ViruJaagupis (samas: 522). Tallinnast pärineb teade, et tagasihoidlike roheliste õitega ja Eestis harva õitsev, kuid viietiste tähesarnaste lehtedega harilik luuderohi on samuti kandnud taevatähe nime (samas: 348). Soomlastel on kelluka (Campanula) perekonna rahvapärased nimed aamutähti ja tähtikukka (Suhonen 1936: 81) arvatavalt tulnud õite kuju järgi ja jõgitakja (Sparganium) perekonna liikide nimi tähtiruoho ümarate ogaliste viljade järgi (samas: 357-358). Tähtheina (Stellaria) perekonna valged kroonlehed meenutavad samuti tähte ja selle järgi on perekonnale ilmselt antud ka ladinakeelne nimi, kuid eestlastel pole selle perekonna liikidel praktiliselt üldse rahvapäraseid nimesid (v.a vesiheinal). Vesitähtheina nimi tähelill (Vilbaste 1993: 439) ja vesiheina nimed tähelill ja tähthein (samas: 606) on

${ }^{3}$ Arvatavasti ei ole siin tõlkeseost ladinakeelse nimega Aster. 


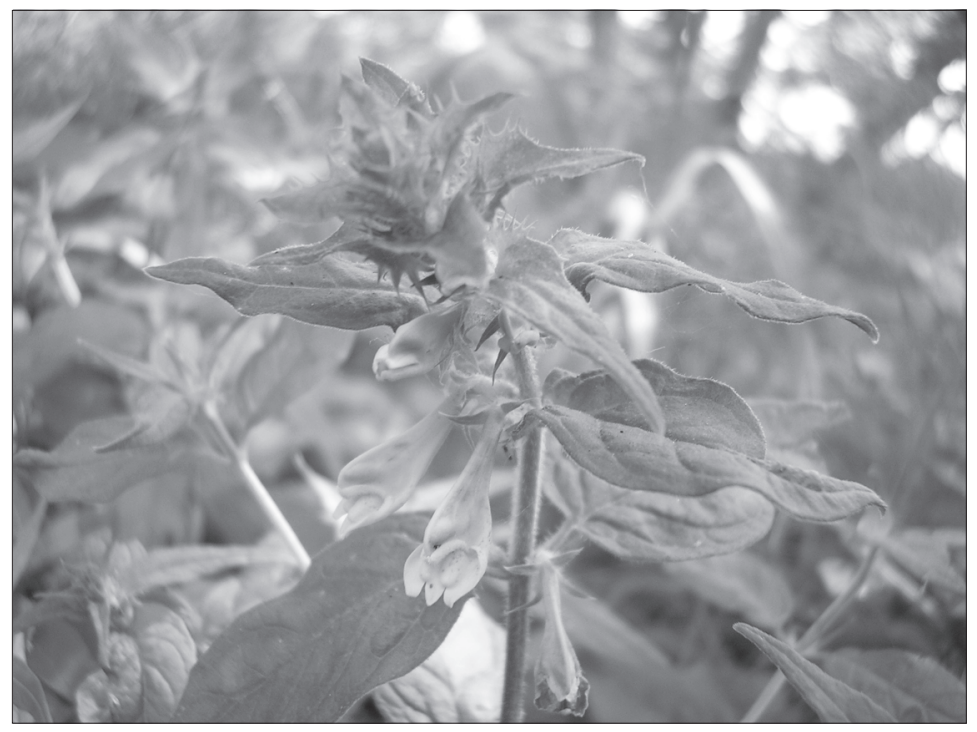

Hariliku härgheina kõrglehed meenutavad kuupaistet, mille järgi on ta omale rahvapärase nime saanud. Pilt: Renata Sõukand ja Raivo Kalle.

levinud vaid kirjanduses ja saadud võib-olla soome keelest, kus selle perekonna 13 liigi rahvapärastes nimetustes on osad -tähtimö, -tähti, tähti(Suhonen 1936: 361-364), aga võib-olla ka saksa keelest (Sternmiere). Nomenklatuurne nimi kollane kuldtäht on Eestis saadud saksakeelse nime Goldstern tõlkest, taime rahvapäraste nimede hulgas on aga ka taevatäht ja tähelill (Vilbaste 1993: 326); soome keeles tähtikukkanen (Suhonen 1936: 159).

Võrdluseks, Eestis vähetuntud ja väikese levikuga seened maatähed, mis meenutavad pealtvaates oma mitmeharuliselt lõhenenud ning allapoole keerdunud väliskestaga tähte, on arvatavalt oma eestikeelse nime saanud ladinakeelse Geastrum tõlkest (Kuresoo jt 2001: 184), samal alusel on tekkinud ilmselt ka soomekeelne perekonnanimi maatähti.

Taevakeha kuu on eestlastel seostunud vaid poolparasiitse eluviisiga hariliku härgheinaga, kelle lillast valge toonini varieeruvad kõrglehed meenutavad kuukuma, mida näitavad rahvapärased nimetused kuulilled, kuuja-päevalilled, kuukannid, kuurohud, kuuvalged jm (Vilbaste 1993: 425). Selle seose on üles märkinud J. H. Rosenplänter oma herbaariumis 1845 . aastal: „Sest siis tedda kuu pea rohhuks hütakse, et temma õied nenda wälja näitawad, kui olleks kuu walguse modi ollewad“(samas). Soomlastel on kuuga seostunud seened: murumuna perekonna liigid ja mustjas maa- 


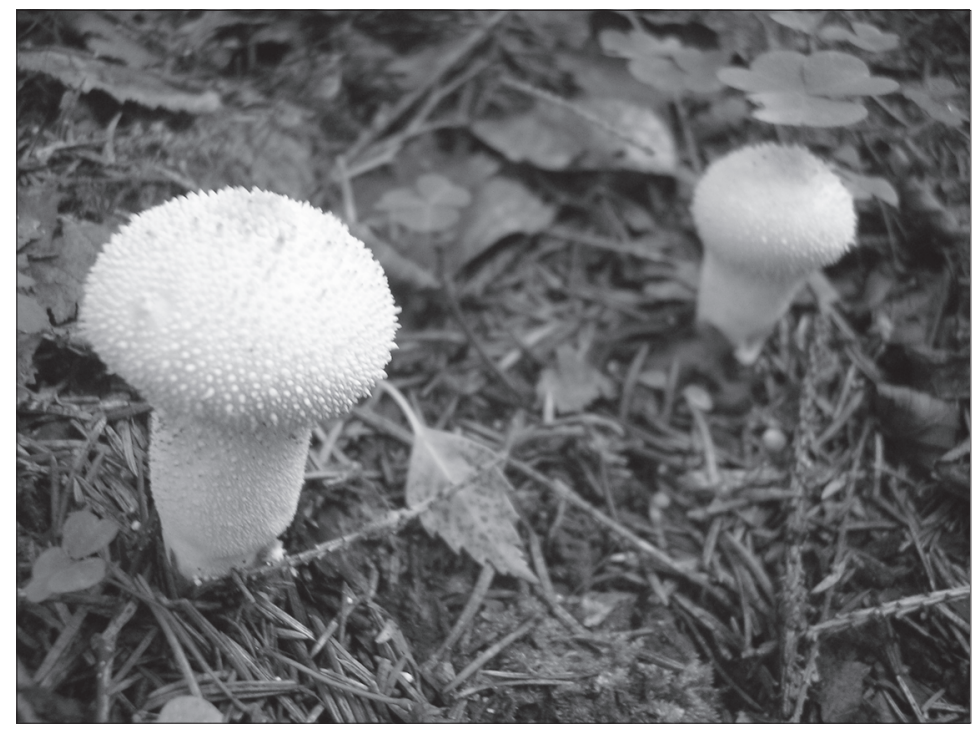

Soomlastel on erinevalt eestlastest murumuna perekonna liigid oma rahvapärased nimed saanud kuud meenutava kuju järgi. Pilt: Renata Sõukand ja Raivo Kalle.

muna, mis oma ümara kuju poolest meenutavad kuud (Suhonen 1936: 212_ 213). Kultuurtaim aed-kuukress on nii eestikeelse kui soomekeelse nime (kuuruoho) saanud ilmselt ladinakeelest nimest Lunaria. Sama kehtib ka pärismaise, kuid tagasihoidliku välimusega ja seega eestlaste hulgas vähetuntud kuu-võtmeheina (Botrychium lunaria) kohta: kuuga seotud nime on ta saanud ladina keelest nii eesti (Vilbaste 1993: 198) kui ka soome keeles (kuutava noidanlukko - Suhonen 1936: 67). Eestis kasvab veel kaks kuutõverohu perekonna liiki, kuid selle nime on taim saanud Vilbaste (1993: 485) hinnangul pigem kuutõvega (menstruatsioon) seotud probleemide ravimisest kui taevast paistvast kuust. Hariliku käbiheina nime kuurohud kohta on aga antud seletus: „Selle rohu teed antakse kuutõbisele inimesele, kes jampsib“ (samas: 509).

Sõna päike sisaldavad nimetused päikesekuld hariliku käokulla ja päikeseroos hariliku kuldkanni ${ }^{4}$ kohta (Vilbaste 1993: 350, 349) on levinud Eestis vaid kirjanduses ja moodustatud kas saksa- või ladinakeelse nime tõlkest, nagu ka soomlastel päevalille nimi auringonkukka (Suhonen 1936: 173). Sagedamini sisaldavad eesti taimenimetused aga päikese tähenduses lühemat sõnatüve päev/päiv, nagu ka ülalnimetatud päevalill, rahvapäras-

${ }^{4}$ Soome keeles auringonkoe, auringon kokeet (Suhonen 173). 
te nimedega veel päevaroos ja päevaketas, kuid ka need lähtuvad saksakeelsest Sonnenblume'st (Vilbaste 1993: 349-350). Pole võimatu, et hariliku päevalille nimed võisid olla eeskujuks ka teise võõrliigi, hariliku saialille nimedele päevarattad, päevaroos, päevalill, päevakollased (samas: 211). Samasse rühma kuuluvad teised korvõielised ja/või kollaste õitega taimed kollane karikakar (päiväkakrad, päivakarud), harilik härjasilm (päevakakar), võilill (päevalill) ja kibe tulikas (päevarohi, päivalill), mis on päikesega seotud nimed saanud ilmselt sarnasuse alusel (samas: 162, 397, 612, 519). Tulles veelkord tagasi eelmises lõigus käsitletud härgheina juurde, võisid ka selle nimevariandid kuu-ja-päevalill, kuupäevarohi jmt viidata just kahele värvile, kuukarva lillade kõrglehtede ja kollaste õite tavatule kombinatsioonile. Kuid vastavat osist leidub ka mõnede taimede nimedes, kellel sellist sarnasust välja tuua ei saa. Mõru vahulille nimed päevaseep, päevalill, päevitusehein, päevituslill ja päivitusrohi (samas: 482) on tulnud sellest, et teda kasutati laialdaselt päevituse eemaldajana. Üks sarnane teade koos vastavate nimetustega leidub sööt-reiarohu kohta (samas: 354). Kas ka väike lemmel ja kahar kirburohi on päeva-alguselised nimed sellest saanud (samas: 394, 488), võib vaid oletada. Kasutamisele äkilise haiguse raviks viitab kollase ängelheina nimi päevahäkitsed (samas: 616), päevaosis võib siin aga märkida õievärvi. Rahvasuust pole kogutud vanemates trükiallikates leiduvaid hariliku äiatari, punase pusurohu ja ümaralehise huulheina nimevariante päevalill ja päevarohi (samas: 380, 584, 288). Kuid soomlastel on kollaste või valgete kroonlehtedega taimede jaoks mitmeid rahvapäraseid nimetusi, mis on seotud päikesega. Selliseid nimesid kannavad näiteks härjasilm, koeratubaka ja hunditubaka perekonnad, teekummel, kesalill, valge vesiroos, harilik nälghein, harilik laanelill ja harilik kullerkupp (Suhonen 1936: 104, 123, 175, 220, 223, 241, 357, 375, 383).

Vähene taevakehade esindatus taimenimedes näitab, et eestlased seostasid taevakehasid ja taimi võrdlemisi kasinalt. Taimede tundmine oli seotud praktiliste tegevustega (arstimine, värvimine jne), millele viitab kordades rohkem rahvapäraseid taimenimesid, sarnasuse alusel moodustatud nimedes võrreldi taimi enamasti loomade-lindude ja mitmesuguste esemetega. Tundub, et n-ö taevased asjad (k.a astronoomilised objektid) ei olnud seotud igapäevaste praktiliste tegevustega - maapealsete asjadega, neist ei räägitud nii tihti. Et aru saada, kas selline reegel oli taimenimede puhul üldine, peame siinkohal välja tooma võrdluseks taevast ja pilvedest lähtunud napid taime- ja seenenimed. Etnoloog Aivar Jürgenson toob välja vaid ühe kandseene nimetuse, mida saab etümoloogiliselt seostada taevaga pilvik, mis viitab pilvele ja mida on kutsutud murdeti veel pilveseeneks ja taevaseeneks (Jürgenson 2005: 257). Pilvetükkideks, pilvepaladeks ja teiste 
sarnaste nimetustega kutsutud ollused võisid olla nii limaseened kui vetikad ja neid nimetati nõnda seetõttu, et nagu kõiki seeni, peeti neidki taevast kukkunuteks (samas: 253-257).

Kristliku kultuuri, eriti selle äärmuslikuma suuna, 18. sajandi vennastekoguduse liikumise mõjul pandi taevased ja maapealsed asjad tihti kokku, et kristlikku õpetust maarahvale arusaadavamaks teha. Näiteks tae$v a$-osisega taimenimed ei viita enam silmaga nähtavale taevale, nagu eespool mainitud pilvetükid meenutasid välimuselt pilvi ja kuulill kuupaistet, vaid paradiisile ja neid kinnistasid religioossed muistendid. Parimaks näiteks on hariliku nurmenuku (Vilbaste 1993: 507) ja alatiõitseva begoonia (samas: 188) rahvapärased nimed taevavõti ja taevavõtmed, ${ }^{5}$ mille aluseks on ilmselt saksakeelne nimetus Himmelschlüssel. Nime seletab näiteks järgmine pärimusteade:

Peetrusel kukkus kuldsete taevavõtmete kimp maa peale. Ta saatis ruttu ingli järgi, aga kimp jõudis siiski enne maa peale. Ingel võttis võtmed maast üles ja viis Peetrusele tagasi.

Maa peale jäi aga võtmetest kuldne jälg. Igal aastal, sel ajal kui võtmed maha kukkusid, ilmub ta uuesti. See kuldne võtmekimp on nurmenukk. (Vilbaste, TN 11, $295<$ Nõo khk., Elva 1. - Priidu Tammepuu < Aime Rosin (1963))

Kolga-Jaanist ülestähendatud hanijala rahvapärane nimetus taevaredel (Vilbaste 1993: 498) on arvatavalt tulnud tema redelit meenutava sulgja lehe järgi, kuid milline kristlik või eelkristlik motiiv sellega seotud on, pole teada.

Kuna eestlastel pole olnud kombeks panna taimedele n-ö ebapraktilisi nimesid, on ka jumalustele ja pühakutele viitavad taimenimed, nt maarjahein, maarjalepp, peetrihain, jumalakäpp, jeesusekäed võõrast algupära (Vilbaste 1993: 64). Sama näitab ka taimemuistendite ülim nappus võrreldes teiste rahvastega, pealegi tugineb suurem osa neist kristlikule taustale ja on levinud rahva hulka tõlkekirjanduse kaudu. Lääne-Euroopa on saanud oma rohked taimemuistendid pärandiks muistsest Roomast ja Kreekast. ${ }^{6}$

${ }^{5}$ Soomlased on taevavõtmeteks kutsunud punast pusurohtu (Suhonen 1936: 211). Taeva-sõna sisaldavad veel kauni põisrohu nimi taivaankukko (samas: 28), hariliku maisi nimed taivaan ruoho ja taivaan ohra (samas: 412) ja ka maajala nimi taivaan sinisilmä (samas: 237).

${ }^{6}$ Siinkohal meenub kohe Kreeka mütoloogiast tuntud tegelane Narkissos, kelle enesearmastus viis lõpuks hukuni ja kelle kehast võrsus lill - nartsiss. 


\section{TAEVAKEHAD METSA- JA PÕLLUTÖÖDEL}

Teated taevakehade mõjust taimede kasvatamisele on suuremalt jaolt seotud muistse agraarkalendriga, mida on põhjalikult uurinud folklorist Mall Hiiemäe (1982, 1989 jm). Ajaloolane Elina Öpik (1981) on teinud kokkuvõtte ennemuistsetest külvinädalatest ja etnograaf Endla Jaagosild (1976) on võtnud kokku viljakoristusega seotud kombed Eestis. Taevakehade mõju metsatöödele on uurinud etnograaf Ants Viires (2000). Siiski pole ükski uurija seni koondanud kokku kogu etnoastronoomias olevat etnobotaanilist materjali. Siinkohal kasutame võimalust ja anname sellest üldise ülevaate. Selleks kasutame väljavõtteid usundiuurija Aado Lintropi koostatud etnoastronoomia andmebaasist „Maailm, taevas ja taevakehad“, millesse on koondatud maailma, planeetide, tähtede ja taevalaotuse kohta käivad uskumusteated (Lintrop s.a.) ja täiendavalt tekste rahvausundi ja muistendite andmebaasist Rehepapp (Kõiva s.a.) Liigitasime tekstid viide kategooriasse, tuues võrdluseks ära ka liivlaste sellekohaseid uskumusi „Liivi rahva usundi“ järgi (Loorits 2000).

Metsaraiet puudutavad uskumused. Arvati, et kui kuu ja päike on korraga nähtaval, on hea raiuda ehituspalke - need ei mädane ära, ning rangi- ning ikkepuid - need ei hõõru hobusel ja härjal kaela ning kukalt. Kui aga sel ajal puu vastu lüüa, kuivab see ära, nagu ka kõik teised puud heli kuuldekaugusel. Palgipuid raiuti noores kuus; samal ajal raiutud hagu ja lehtpuud pidid ruttu võsa tagasi kasvatama. Kui taheti, et ehituspuud seisaks kaua ja ehitisse majavamm sisse ei tuleks, siis pidi neid raiuma täiskuuga. Samuti raiuti ehituspuid vana kuu kõval ajal ja kui taheti võsast lahti saada, siis raiuti seda samuti vanal kuul. Puid lõigata soovitati ka kuu loomise ajal, siis on need terved ja kõvad ning ei lähe koitama.

Ka liivlaste teated kuujälgimisest metsatöödel on vastukäivad. Arvati, et lehtpuid peab raiuma kuu esimeses ja tarbepuid viimases veerandis. Aga kui taheti, et puit kõva püsiks, raiuti okaspuu noores kuus ja lehtpuu vanas kuus. Kui taheti, et okaspuu keerud ei torkaks, raiuti neid vanas kuus ja lehtpuud noores kuus, siis nad püsivat kauem ja kuivavat kergemini (Loorits 2000: 310).

Külviga seotud uskumused. Nisu, rukist, otra ega loomavilja ei tohtinud külvata, kui kuu ja päike on üheaegselt taevas, sest kuu vaatab terad ära ja need lähvad tahma. Sel ajal ei tohtinud ka linu külvata, sest nad jäävad väikseks ja ilma kiuta või võtab põud nad ära. Kunagi ei tohtinud külvata, kui kuu oli kummuli ja tal oli küür seljas. Samuti ei tohtinud kuu loomise ajal külvata, sest siis tuleb ikaldus. Külvata soovitati kas enne vana kuu lõppu või kui noor kuu on mõni päev vana, aga üldiselt soovitati kaera, otra ja teisi vilju külvata ikka noores kuus, siis idanevad ja kasva- 
vad nad paremini ning annavad suurema saagi, on ka tugevama kõrrega ning küpsenud seeme ei varise maha. Noore kuu ajal külvatud viljale ei tulevat tungaltera sisse, mis vanal kuul külvates pidi juhtuma. Kuid on ka teateid, et teravilja peab hoopis külvama vanas kuus, sest noores kuus külvatud vili ei kasva ning põld läheb umbrohtu täis. Täiskuu oli valdavalt parim aeg viljakülviks. Linu ei külvatud, kui kuu on kõrb; ${ }^{7}$ neid soovitati külvata, kui kuu on pesas (s.o loomata) või noore kuuga, teises teates öeldi hoopis vastupidist: noore kuuga külvatud linadel ei ole head kiudu loota. Tatraid soovitati täiskuuga külvata. Täiskuu, kõhuga (s.o esimese veerandiku) kuu ja noore kuu ajal ning kuuvaheajal soovitati aga kaunvilju külvata. Teistes teadetes jällegi arvati aga vastupidi, et noorel kuul külvatud herned ei kee pehmeks, kasvatavad liigselt kasve ja on külmaõrnad. Kui aga taheti, et herned ei ussitaks, külvati neid hoopis vanakuu neljapäeval. Köögivilja külvati samuti vana kuu ajal.

Liivlastel oli uskumus, et vanas kuus pidi vilja külvama hommikul ja noores kuus õhtul, siis vili kasvab paremini. Suvivilja (otra, nisu) pidi külvama noores kuus, et nad enam õitseksid ning oleks palju teri. Ka oli arusaam, et teravilja ja üldse maa peale kasvavat külvatakse noores kuus, maa alla kasvavat vanas kuus. Ühe teate järgi külvati nisu siis, kui kuud ei ole taevas. Herneid külvati vanas kuus ning kui taheti täis oakaunu saada, külvati neid siis, kui täiskuu oli kolm päeva vana, noores kuus külvates pidid nad ainult oitsema (Loorits 2000: 311).

Istutamisega seotud uskumused. Kui kuu ja päike korraga taevas, ei tohtinud kapsaid istutada ega kartuleid maha panna. Lilli ja viljapuid soovitati istutada noore kuuga. Üldse soovitati taimi istutada kõhuga ja noore kuu ajal, kuid sibulaid hoopis vanas kuus või ka noore kuu alguses. Kaalika- ja kapsataimi soovitati istutada täiskuuga. ${ }^{8}$ Arvati, et kui kartul kuu loomise ajal maha panna, kasvab ta hästi, kuid ka vastupidi, et nii tehes läheb ta hoopis kärna ja parem aeg kartulipanekuks on vana kuu. Et kartul hästi pehmeks keeks, pandi ta maha noorel kuul. Kuid valdavalt soovitati kartulit panna täiskuu ajal. Noore kuu ajal soovitati noori vilja-

7 Tekstides ei täpsustata, millist kuu faasi sellega mõeldakse: Ku on kuu kõ ${ }^{\prime} b$, sis lina es külite. Ei tää, mis see „kuu kõr'b“om. Peremees naar's abemesse, ku küssin. A seda ta's ütle, määnd see „kuu kõr'b“ om. Tal ol'l ka ninda ilus lina! (RKM II $145,194 / 5$ (2) Hel). Vrd kuu on kõr'b, ta om suur ja punane, sõss ku ta tõususs Krk (EMS IV: 273).

8 Järgneva teksti põhjal pole üheselt mõistetav, kas soovitatakse istutada pilves ilmaga või hommikul ja õhtul, mitte keskpäeval ja öösel, vm: „Kui kapsid ehk kaala siis külvad, kui pääv ülevel on, siis kõrvetab päike nad ära. Kui kuu paistab, siis kolletavad ära“ (E 16960 (81) < Viljandi khk, Vana-Tänassilma m H. Jaanson (1895)). 


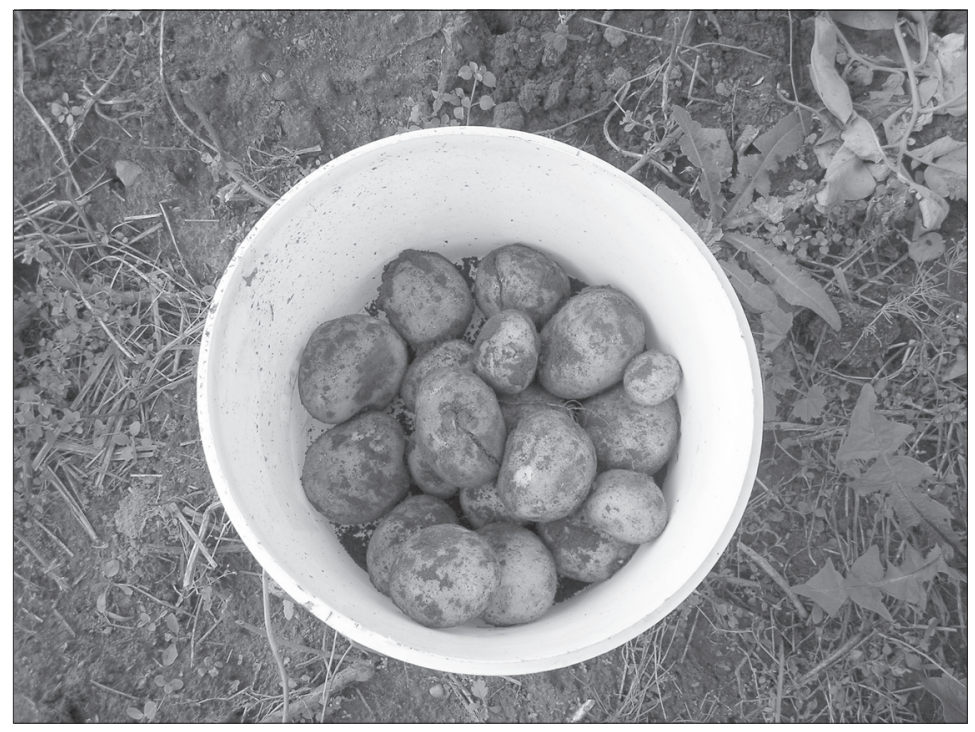

Kartul meenutab oma ümarusega kuud, see võis olla põhjus, miks tema istutamisel rohkem ka kuufaasidega arvestati. Pilt: Renata Sõukand ja Raivo Kalle.

puid pookida. Levis arusaam, et taimed, mis allapoole kasvatavad, istutatakse (külvatakse) vana kuuga, mis peale, need noores kuus.

Liivlastel oli üldine uskumus, et kartuleid pannakse vanas kuus, siis on palju mugulaid, kui noores kuus, siis kasvatab palju õitsvaid varsi. Arvati veel, et hea on kartuleid panna, kui kuu läheb vanaks või täiskuu ajal. Sibulaid külvati vanas kuus, noores kuus istutades lähevad nad putke, kuid noores kuus neid külvates pidi jälgima, et tehtaks seda õhtul (Loorits 2000: 311).

Saagiga ja selle koristamisega seotud uskumused. Viljakoristuse kui aasta kõige kiirema tööaja jooksul polnud endisel põllupidajal mahti taevakehasid uurida, jälgiti rohkem soodsaid ilmaolusid. Endla Jaagosild (1976: 32) on leidnud vaid ühe Rõugest pärit teate, kus öeldakse, et viljalõikuse alustamiseks on soodne täiskuu aeg. Kui vili juba küps oli, siis oodati täiskuud, mis pidi lõplikult vilja küpseks tegema. Kartuleid soovitati sügisel võtta noore kuu ajal, sest vana kuu ajal võetud kartul pidi mädanema minema.

Halvaks endeks loeti olukorda, kui veebruaris on päike ja kuu korraga taevas. See tähendas, et lauritsapäeva (10. august) ja pärtlipäeva (24. august) vahel võtab külm vilja ära. Ka tähtede ja tähtkujude järgi ennustati saaki. Kui koidu- (hommikune Veenus) ja ehatäht (õhtune Veenus) kõrgelt käisid, ennustas see head viljasaaki. Selge aotäht (Veenus) ennustas sa- 
muti head saaki, kuid hägune aga hoopis nälga. Sabaga tähe (komeet) ilmumine tähendas üldiselt viljaikaldust. Saaki ennustati ka tähtkujude järgi: head saaki oli oodata, kui Reha ja Koodid (Orion) ning Sõel vana-aastal maha lähevad.

Muude töödega seotud uskumused. Noore kuuga ei tehtud vihtasid ega luudasid, sest siis siginevad kirbud ja selline viht paneb ihu sügelema. Vihtasid tehti vanal kuul, siis arvati need olevat mitme haiguse vastu. Noore kuu ajal niidetud hein pidi kokku minema, aga rohkem ädalat kasvatama. Kapsaid tehti sisse kuu loomise ajal, siis said nad hästi pehmed.

Liivi rahva uskumuse kohaselt pidi põldu, kus on palju umbrohujuuri, vanal kuul kündma, siis kaduvat need ära (Loorits 2000: 311).

Võib öelda, et tähtsaim taevakeha eestlaste taimekasvatuse mõjutajana oli kuu. Võrdluseks, mordva mütoloogias on taevakehade mõjust taimedele ainult napp teade kuu kohta, öeldakse vaid, et kahaneva kuu ajal hoiduti külvamisest ja juurviljade istutamisest (Devjatkina 2008: 97). Kuuloomise õige aeg oli oluline mitmete tegemiste juures ja selle kindlakstegemisel kasutati Lõuna-Eestis (Maarja-Magdaleenas, Rõuges, Räpinas, Tarvastus ja Kõpus) just taimede abi - veega täidetud pange asetatud toores pihlakapulk vajus põhja, kui kuu ära oli loonud, ja tõusis täiskuuga jälle pinnale.

\section{KUUFAASID KÜLVIKALENDRITES}

Kuufaaside ajal tehtavate tööde normidest ja keeldudest pole etnoastronoomia uurija Andres Kuperjanov süsteemi leidnud, vaid mainib selle kohta, et „traditsioonis on kinnistunud sajad reeglid, kuidas erinevates olukordades ja erineva kuu faasi korral käituda ja igast sellisest reeglist leidub omakorda sadu erandeid“ (Kuperjanov 2003: 82). Seetõttu pole ka ükski uurija enne teda ega ka hiljem püüdnud luua Eesti taimeastronoomia ühtset süsteemi. Mall Hiiemäe toob küll välja tõsiasja, et teraviljade külvi puhul (rukis, oder) vaadati kuufaase vähem kui kartuli ja herne puhul (kartul ja hernes meenutasid rohkem oma kujult kuud) ja kõige rohkem vasturääkivusi on linakülvil. Samuti on Kagu-Eestis kuupärimuse vastukäivust suurendanud ebamäärased kujutlused kuufaaside vaheldumisega kaasaskäivast pehmest ja kõvast ajast, mille paiknemist konkreetses kuus pole pärimustekstide põhjal võimalik enam kindlaks teha (Hiiemäe 1989: 164-166). Illustratiivselt on kuu pehmetest ja kõvadest aegadest nelja eri tõlgenduse alusel kokkuvõtte teinud Andres Kuperjanov (2003: 89). Tänapäeval kasutab kuu pehmeid ja kõvu aegu tööde ja tegemiste suunamiseks Maavalla Koda oma kalendrites (nt Kütt jt 2007), mida ka Maalehe lisa 
Targu Talita igal kuul ära trükib. Selline aegade fikseerimine ei saa siiski olla vanem kui 150 aastat, sest siis hakkas eestlaste tsükliline ajakäsitlus asenduma tasapisi lineaarse ajakäsitlusega ning tähtsamateks ajaarvestajateks said kell ja trükikalender (vt pikemalt Pärdi 2008: 483-485).

Ühtse kuufaasidel põhineva süsteemi puudumine lõi eelduse selle importimiseks, mis kajastub kalendrisabade keerulistes külvikalendrites. Lauri Vahtre on võrrelnud mitmeid omaaegsetes kalendrites ilmunud töid ja tegemisi suunavaid juhiseid ja leidnud, et need olid tihti üksteisele vastukäivad, kuid sellegipoolest suurendas nende olemasolu tunduvalt kalendrite läbimüüki. 19. sajandi keskel hakati rahva soovile vastu tulles ka külvinädalaid kalendrites avaldama (vt Vahtre 2000: 125-127). Kuigi need 7päevased külvinädalad ei sobinud arhailise külvinädalate süsteemiga, aitas kalender siiski kaasa sellele, et uus süsteem eksisteeris veel 20. sajandi keskpaigani (vt nt Hiiemäe 1982: 107-108). ${ }^{9}$ Trükikalender on olnud eestikeelse varasema ajaloo-alase maailmapildi kujunemise oluliseks mõjutajaks (Paatsi, Paatsi 2008: 11-12) ja võib oletada, et nii mõnedki folkloorikogudes talletatud juhised kuufaasidega arvestamiseks ongi kalendritest kohalikku pärimusse jõudnud, asendades või moondades arhailist süsteemi.

Kuu nii suure mõjuga arvestamine ei ole ilmselt kunagi olnud eesti algupära, selle juurutajateks olid mh baltisakslastest mõisnikud. Baltimaade toidu- ja põllunduskultuuri ajaloo uurija Ulrike Plath (2010) on leidnud mitmeid teateid 18. sajandist selle kohta, kuidas mõisavalitsejad on talupoegadele heas usus õpetanud kuu mõjudega arvestamist põllutöödel, mis Lääne-Euroopas oli sel ajal küllaltki levinud, kuid eestlasest talupoeg suhtus kuusse umbusuga ja jälgis oma põllutöödel hoopis tuule suunda, öeldes, et see on jumala otsene saadetis. Reegliks oli, et „kõva“ (põhja- ja idakaare-)tuul külmetab, toob kuiva ja suretab, „pehme“"(lõuna- ja lääne-) tuul toob niiskust, soojust ja edendab elu (Viires 2000, Hiiemäe 1982 jt). Ka liivi rahva uskumuses on säilinud rohkesti teateid tuule suunaga arvestamisest, nt: „Vanakuu reedel ja põhjatuulega pidavat küntama maad, kus on palju juuri: siis juured kaduvat ära; herneid peab külvama vanas kuus, ja kui on ida tuul, siis on puhtad herned, siis ussid ei söö ära" (Loorits 2000: 311). Ka Ants Viires märgib, et kuufaasidega arvestati metsatöödel küllaltki meelevaldselt ja vastukäivalt, kuid sealgi jälgiti hoolega tuule suundasid (Viires 2000: 46). Mall Hiiemäe (1989: 170) tõdeb samuti, et kuigi meteoroloogilised külviorientiirid jäävad adekvaatsuselt fenoloogiliste-

9 Tasub meenutada, et eestlastel oli ühena vähestest Euroopa rahvastest veel 20. sajandi algul käibel arhailine tagant ettepoole loetav külvinädalate süsteem, mida arvatakse olevat kasutatud eelkristlikul ajal ja mis mujal Euroopas oli juba ammu kadunud (Öpik 1981: 194). 
le alla, lähtuvad nad siiski viljakülvamisel olulistest agrometeoroloogilistest nõuetest. Teisal on ta tunnistanud, et „kahjuks on folkloorse ja etnograafilise materjali kogumismetoodika olnud sageli selline, et teatava traditsiooni kirjapanek vahendab vaid ühe neist tegureist [arhailine külvinädalate süsteem, fenoloogiline vaatlus, kuufaasid, ilmavaatlus], näitamata, millisest või millistest põllumees oma töös tegelikult juhindus“ (Hiiemäe 1982: 106)

Tänapäevaks on külvikalendritest saanud ajalehtede, ajakirjade, kalendrite lahutamatud osad. Näiteks Eestis laiemalt tuntud autorite, sakslaste Maria ja Matthias Thuni külvikalendreid saab lugeda nii elektrooniliselt, ${ }^{10}$ 1990. aastal ilmuma hakanud aastaraamatutest kui Maalehe lisast Targu Talita. Vene kogukond Eestis on aga suuresti mõjustatud naaberriigis väljaantavast kirjandusest, tuntuim autor on astroloog Tatjana Borštš (nt Borštš 2009). Erinevus tänapäeval ilmuvate külvikalendrite vahel enam nii suur ei ole, enamasti vaid ühepäevane, olenevalt kuu öise muutuse lugemisest kas eelnevale või järgnevale päevale. Kasutuses on need arvatavasti rohkem hobipõllumeeste seas, suurtootjad peavad siiski tegema pigem ilmastikul põhinevaid otsuseid külvide ja lõikuste kohta. Kas need keerulised külvikalendrid on aga kõigile mõistetavad? Kasutajate tagasisidet saab teada vastavasisuliste ajaleheartiklite kommentaariumitest ja foorumitest:

[---] Aga on veel see, et Thuni külvikalendri järgi on nö õiged päevad seemnete külviks. S.t näiteks siis Sõnnis olev (ja siin ongi see punkt, et ma ei saa aru mis seal Sõnnis on Thuni kalendersüsteemi järgi) päev on hea juurikate külvamiseks.

Meie igapäevane tavahoroskoop ehk siis kuukalender erineb Thuni kalendrist. S.t kui tavahoroskoobis on Kuu Sõnnis siis Thuni kalendri järgi ei ole Sõnni päev. Nii - hakkasin mina netist uurima ja avastasin, et meie igapäevased Kuu kalendri sodiaagid on saksa külvikalendris nimetatud troopilisteks sodiaagimärkideks. Ja siis leidsin veel erinevuse selle aasta Saksamaa Thuni külvipäevade ja meile eeslastele tõlgitud selleaasta Thuni kalendri külvipäevade vahel. See on see mida ma küsisin - et kas keegi teab - miks? [---] (Liisi, 03.07.2008 6:19 pm)11

10 Mondkalender Astrologie - Kostenlose Berechnung online auf http:// www.astrologie-info.com. http://www.bunkahle.com/astrolog/mocal.cgi [viimane külastus 21.03.2010].

${ }^{11}$ Foorum Tuulepesa. Thuni kalendrist. http://tuulepesa.zzz.ee/viewtopic.php? $\mathrm{t}=4205$ [viimane külastus 21.03.2010]. 
olen juba ligemale 20 aastat ostnud mangi horoskoope ja Maria ja Matthias K Thuni külvikalendreid. kui neid loen, siis paar päeva on eksimisi ka. aga thunid pole eesti ajavööndis. natuke põen oma kehvapoolse hariduse pärast, et ma lihtsalt ei oska kõiki tarkusi välja lugeda. thunide kalendris oli see MAAVÄRINA KALDUVUS 15 KUUPÄEVAKS ja suveti äiksepäevad kipuvad ka ajavööndi tõttu päevakese võrra eksima. aga praegune pikaajaline härmatis kisub vanarahva tarkuste järgi pikemale pikse lainele südasuvel. (maapenskar, 17.01.2010 18:06) ${ }^{12}$

Külvikalendrite propageerimise tagajärjeks ongi, et ei vaadata enam kuud kui taevakeha, vaid vaadatakse paberit. Külvikalendrid on muutunud nimelisteks, nad pole enam anonüümsed nagu sajandeid tagasi. Kalendri koostaja nimi justkui rõhutaks selle usaldatavust, muutudes brändiks. Siiski, nagu ülaltoodud näidetest selgub, on ka analüüsivaid kasutajaid, kes võrdlevad eri kalendreid omavahel, kuid süsteemi keerukuse tõttu käib see paljudel üle jõu.

\section{TAEVAKEHAD JA TAIMRAVI}

Kuna endisaegsetes kalendrites soovitati kuu faase arvestada ka ravi alustamisel, ${ }^{13}$ siis uurisime, kas eesti rahvameditsiini taimravipärimusse on midagi sellekohast jõudnud. ${ }^{14}$ Selgus, et üksikuid teateid siiski leidub, enamasti vana kuu kohta. Nii näiteks on vanal kuul ravitud nn väge omavate taimedega, mille raviviisidki olid rohkem rituaalse kui praktilise iseloomuga. Nendeks olid pihlakas (kooljaluu, siutõve, maa-aluste, tuulerõugete raviks; prussakate ja täide peletamiseks) ja lepp (soolatüügaste, sügeliste raviks). Kahes tekstis soovitatakse pihlaka koort ja õit raviks võtta just vanal kuul. Veel leidsid vanal kuul kasutust sibul (soolatüügaste raviks), kaseviht (kirpudest lahtisaamiseks), maavitsad (halltõve raviks), vereur-

${ }^{12}$ Ain Kallis. Pühvliaasta tõi ilma osas kõiksugu pulli. - Maaleht 17.01.2010 Kommentaarid: http://www.maaleht.ee/news/loodus/loodusuudised/ain-kallispuhvliaasta-toi-ilma-osas-koiksugu-pulli.d?id=28482379\&com $=$ [viimane külastus 21.03.2010].

13 Tuntum enne II maailmasõda ilmunud selleteemaline kalender oli E. Heisleri väljaantud „Astroloogiline kalender“, mis sai ilmuda 5 aastakäiku (1933-1939). Nagu nimigi ütleb, sisaldas see lisaks kuu mõjudele igakülgset astroloogilist teavet ennustustest raviõpetusteni.

${ }^{14}$ Andmete analüüsiks on kasutatud etnobotaanilist andmebaasi HERBA (Sõukand, Kalle 2008). 
marohi (soolatüügaste raviks) ja tuulepesa (tuulest saadud haiguste raviks). Nende taimede kasutamine just vanal kuul oli üks osa rituaalist.

Noorel kuul ravimisest teateid ei ole, küll leidub tekste nõidumisest, milles taime on kasutatud vahendajana, nagu näiteks:

Tüdrukud ära ohate ninda, et tidrukul esiütsinde laits om. Selles otsitse üits sinande puu, kellel külle pääl ragu sehen om ja säält rao vahelt üits pihlapupuu välla kasunu om. See pihlap lõigatse säält ära noorekuu sehen ja laasitse vastuoksa ära, ladvast laasma hakaten. Siis piab selle kepige ütesse uiska enne jüripäeva ära matterdema. Nüüd kus sa selle kepige näüdad üte tidruku pääle ja ütled, et temal piab laits oleme, sis sündumed selle tidrukule laits. (E 1367/8 (21) < Halliste khk., Uue Kariste v. - Otto Sapas (1893))

Vähestes ravitekstides on mainitud teist taevakeha, päikest. Neis teadetes väidetakse, et päike ei tohi ravimtaimede kuivamise ajal neile peale paista, sest võtab lõhna ja rammu. Aga on ka teateid, et ravimtaimi peab kuivatama just päikese käes. Väga suure tõenäosusega on need soovitused võetud kirjandusest. Näiteks kirjutatakse endises ülipopulaarses ravimtaimeraamatus: „Ei ole soovitatav (enamasti on isegi keelatud) kuivatada päikesepaistel, sest päikesekiirte mõjul muutub taime värvus ja väheneb toimeainete hulk, eriti õites ja lehtedes. Mõnede taimede juuri ja juurikaid võib kuivatada ka päikese käes. Mahlakad marjad (mustad sõstrad, mustikad jt.) pannakse õhukese kihina ning lastakse neil enne kuivatisse asetamist päikesepaistel närbuda“(Tammeorg jt 1984: 12).

Keskaegse Euroopa kultuuripildis mängisid taevakehad inimese tervise, haiguste ja ravi juures olulist rolli. Näiteks süüdistasid Prantsuse õukonna arstid 1348. aasta esimese muhkkatku laine tekitamises Saturni, Jupiteri ja Marssi, mis 14. märtsil 1345. aastal olid konjuktsioonis ning põhjustasid sellega õhu ülekuumenemise, millest alguse saanud miasm tekitas haigete kehadele katkumuhud (Watts 2003: 12). Akadeemilises meditsiinis säilisid astroloogia elemendid kuni 18. sajandi alguseni, näiteks pidas kuulus inglise arst Richard Mead (1673-1754) siis veel võimalikuks kuu mõju haigustele ja tervisele (Scarlett 1941: 618).

17. sajandi Inglismaa üks kuulsamaid ravimtaimeraamatuid „Culpeper's Complete Herbal“, mille kirjutas Cambridge'is hariduse saanud apteeker, arst ja astroloog Nicolas Culpeper (1616-1654), toonitab taimede kuuluvust (owned by) kindlatele planeetidele, millest tulenevalt väljendub ka nende mõju: näiteks alluvad porgand ja köömen Merkuurile (Culpeper 1995 [1653]: 58-59), nõges ja küüslauk Marsile (samas: 179, 115), tamm Jupiterile (samas: 181), maasikas Veenusele (samas: 241) jne. Taimeastroloogia 
on tõlkekirjanduse kaudu jõudnud ka eesti keelde (nt Silvano 1935, Muir 2003, Hughton 2009), kuid esimese tõlke mõju pärimusele ei ole fikseeritud ning kahe viimase kandumist folkloori pole seni uuritud.

Veel 20. sajandi esimesel poolel polnud võõrapärane astroloogiaharrastus eestlaste hulgas kuigi levinud. Tähtsamaks allikaks, milles soovitati taimi astroloogia põhimõtete järgi kasutada, võib lugeda sajakonna tellijaga ajakirjas Vaimsuse Ideoloogia läbi mitme numbri ilmunud E. Silvano artiklit „Arstimine kodumaal kasvavate taimedega okkultalusel“ (19331935). See oli väga keeruline õpetus, mille järgi pidi taimedega ravimisel jälgima taimede ja nende osade allumist planeetidele, Kuule ja Päikesele, arvestades nädalapäeva ja isegi kellaaega. Silvano õpetuse põhjal mõjutavad näiteks neitsi tähtkujus sündinuid Merkuurile alluvad taimed: maikelluke, köömned, kadakas, lavendel, till, mirt, pastinaak, sõnajalg ja koirohi (Silvano 1935: 12).

Silvano õpetuse levikust pärimusse pole andmeid, kuid 2007. aastal taasavaldas proviisor Ain Raal selle lihtsustatud kujul oma raamatu ühe peatükina. Ta iseloomustab seda uue terminiga astroherbalism (vt Raal 2007: 43-49), mis on Google'i andmetel kasutusel ainult Eesti saitidel. Kuna see termin on väga tabav, siis aitavad ka käeseoleva artikli autorid meeleldi kaasa selle levitamisele. Ain Raali raamatust on omakorda lihtsustuse teinud alternatiivravitseja Mercedes Merimaa (2010). Need käsitlused on ainult ühed paljudest 21. sajandil Eestis ilmunud selleteemalistest raamatutest, millest enamik on küll tõlkekirjandus. Nende koguarvu on siinkohal raske nimetada, sest sellekohast teavet ilmub nii ravimtaime-, tervise- ja ka astroloogiaraamatutes. Näiteks Ada Muiri teoses „Päikesemärkide ravimtaimed ja tervisetoidud" antakse ülevaade ravimtaimedest üldiselt, eri sodiaagimärkide mõju all sündinud inimeste levinumatest terviseprobleemidest ja lõpuks antakse vastav taimravisoovitus (Muir 2003). Nagu E. Silvano ravisoovitused, nii on ka Ada Muiri omad mõeldud astroloogiast rohkem teadvale inimesele. Välja on toodud küll igale sodiaagimärgile sobivad taimed, näiteks neitsi tähtkujus sündinute ravimtaimedeks on pakutud tihashein, apteegitill, salatsigur, lagritsa-magusjuur, till ja punane juudinõges (Muir 2003: 79-81), kuid nende taimede kasutamisel on mitmed reeglid. Peamiselt peab jälgima oma tähtkuju mõjutavat planeeti ja selle pingeid teiste taevakehadega. 2009. aastal ilmunud põhjalikus „Astroloogilises apteegis“ on neitsi tähtkujus sündinute taimeloend jäänud märksa tagasihoidlikumaks, mainitakse vaid palderjani ja fenkolit e. apteegitilli (Houghton 2009: 77-78), raamatu lõpust leiame jällegi keerulise juhendi planeetide ja sodiaagimärkide vaheliste seoste määramiseks. Arvukatele tõlkeraamatutele lisaks on hakanud ilmuma ka eesti autorite koostatud teoseid, näiteks võib tuua Ragna Malmi koostatud „Ilu astroloo- 
gia“ (2004). Seegi raamat soovitab neitsi tähtkujus sündinutele Merkuuri mõju all olevaid taimi, milleks on münt, kaneel, tatar, kaer, hirss, õunad, kabatšokid, astrid, kadakas ja köömen (Malm 2004: 155). Samuti õpetatakse neist tegema siirupeid, teesid ja maske. Keeruline planeetide seisu jälgimine on seekord vahele jäetud.

Niisiis selgus, et eri raamatutes ühele sodiaagimärgile soovitatud taimed suuremal või vähemal määral kattuvad ning taimede valik on küllalt suur. Arvestatud on ka sellega, et neid Eestis loodusest või poest saada oleks, kahtlane on ainult punase juudinõgese kättesaadavus.

Arvestades astroherbalismi-teemalise kirjanduse kättesaadavust ja arvukust, jätab see kindlasti oma jälje ka pärimusse, kuigi Ain Raali arvates pole see tänapäeval eriti laialt levinud ning kuulub herbalismi äärmuslikumate ja ebateaduslikumate harude hulka (Raal 2007: 48). Siiski on sellel suunal Eestis oma järgijaskond. Näiteks võib tuua ühe ajaleheartikli kommentaari väljavõtte:

[---] Muide Tatjana Gorbunova taimeravi käsiraamatust leidsin endale kõige paremini sobiva ravimtaime, mis on välja toodud raamatu lõpus, kus on juttu haigussoodumustest seoses sodiaagimärkidega. Ja igale sodiaagimärgile sobivad ravimtaimed. (Ja tass iisopiteed teeb tõepoolest viletsa enesetunde puhul lausa imet.) Kusjuures ma varem ei teadnud sellise ravimtaime olemasolustki. [---] (Maret, 07.05.2006 $11: 53)^{15}$

Astroherbalismiga on seotud ka viimastel kümnenditel meieni jõudnud nn puuhoroskoobid, mis nimetavad eri kuupäevadel sündinud inimesi eri puuliikide järgi, kuigi tähtkujudega sellel enam otsest seost ei ole. Järgnev näide on ajendatud kas „Druiidide horoskoobist“(1992) või „Druiidide puuhoroskoobist" (2000):

[---] Kuna olen puuhoroskoobi järgi pihlakas tunnen suurepäraselt pihlaka tervendavat mõju [---] (EFA I, 124, 3 (2006))

Druiidide puuhoroskoobi järgi on pihlakainimene sündinud ajavahemikul 01.04-10.04 või 04.10-13.10 (Heinonen-Rivasto 2000: 30-31).

Kõigele vaatamata on astroherbalism jäänud senises eesti taimravipärimuses marginaalseks. Oma osa selles on mänginud ilmselt piiratud levik varasemal ajal, aga ka õigete valikute keerulisus. Kõige tõenäolisemalt puudub inimestel vajadus uue ravimtaimevaliku süsteemi järele, sest ju-

15 Arko Olesk. Uurimus kummutab horoskoopide tõesuse. - Postimees, 08.05.2006. Kommentaarid. http://www.hip.ee/080506/kommentaarikeskus.php? ARTIKKEL_ID=200565\&TASK=KOMMENTAARID [viimane külastus 21.03.2010]. 
hindutakse traditsioonilisest taimekasutusest. Alles siis, kui traditsioon katkeb või ei paku see lahendust, võetakse selle taaselustamise eesmärgil kasutusse kirjanduse kaudu saadud teadmised (vrd Sõukand, Kalle 2010).

\section{KOKKUVÕTTEKS}

Eestlastel, nagu soomlastelgi, on tähtede järgi nime saanud sarnasuse alusel viie või rohkema õiekroonlehega taimed. Erinevuseks võiks nimetada seda, et soomlastel on ka kellukaid ja jõgitakjat täheks nimetatud. Kuu ja päikese puhul lisanduvad sarnasusnimetustele praktilisel alusel kuuga seotud haiguste ja päevituse vastu kasutatud taimedele antud nimed. Kuud meenutanud taimi on napilt: eestlastel vaid harilik härghein, soomlastel hoopis ümar seen maamuna. Erinevus on päikese järgi nime saanud taimede hulgas: kui soomlastel on seitse liiki ja kaks perekonda valgete ja kollaste kroonlehtedega taimi päikese järgi nimed saanud, siis eestlastel ainult kolm, ühine on vaid harilik härjasilm. Kultuurtaimede, nt päevalille sarnased nimed on rahvusvahelise taustaga. Taevaga on eestlastel seostunud vaid seened: pilvik ja täpsemalt määramatud algseened, nn pilvetü$k i d$, soomlastel on aga taeva-osisega rahvapärased õistaimenimed põisrohul, maajalal ja maisil. Niisiis on soomlaste taimenimede kosmoloogia märkimisväärselt kirjum.

Tähtsaim taevakeha, mida eestlased ja liivlased oma taimedesse puutunud tegevustes jälgisid, oli kuu. Nagu ka eelkäijad, ei püüdnud autorid arhiivimaterjalide põhjal leida selles valdkonnas reeglipära, sest andmed kuuseisudega arvestamisest on väga vastukäivad. Eestlastele ja liivlastele on ühine see, et vana kuuga külvatakse ja istutatakse neid taimi, mis allapoole kasvavad, noore kuuga neid taimi, mis ülespoole kasvavad. Segadus muus osas võis tulla 18. sajandist alates ilmunud kalendrite mõjul, kus tihti avaldati ekslikke andmeid kuu kohta. Külvikalendrid on tänapäevaks saavutanud laia leviku nii trükisõnas kui internetis, kuid ka praegu tekitavad need kasutajates segadust.

Eestlaste vanemas taimravipärimuses leidis kajastust ainult üks taevakeha - kuu - ja sedagi seostati väge omavate taimeliikide pihlaka ja lepaga. Lääne-Euroopa keskaja astroherbalism jõudis seal taanduda 18. sajandi alguseks ja arvatavasti jäi see eestlastele tol ajal tundmatuks. Eestikeelsesse kirjasõnasse jõudis see alles 1930. aastatel ning uuesti alates 20. sajandi lõpukümnendist ning on tänapäeval hõivanud kirjanduses seni täitmata niši. Kuigi astroherbalismi põhimõtted on keerulised, leidub sellel siiski vähesearvuliselt järgijaid. 
Üldiselt lubab etnoastronoomia ja -astroloogia vähene seotus taimekasutusega järeldada, et taimepärimuse kui praktilise ja ellujäämise seisukohalt olulise teadmise puhul juhinduti eeskätt traditsioonilistest arusaamadest ning kõik uus võeti vastu ettevaatlikult ja valikuliselt, kaootiliselt vana süsteemiga integreerides. Alles 20. sajandi lõpus, kui said kokku katkenud traditsioon ning massiline astroherbalismi ja külvikalendrite levik, tekkis võimalus viimaste nähtuste laiemaks levikuks pärimusse.

\section{KIRJANDUS}

Borštš 2009 = Татяна Борш. Лунный посевной календарь на 2010 год. Москва: Астрель 2009.

Culpeper, Nicolas 1995 [1653]. Culpeper's Complete Herbal. Hertfordshire: Wordsworth Editions.

Devjatkina, Tatjana 2008. Mordva mütoloogia. Tartu: EKM Teaduskirjastus

Eelsalu, Heino 1985. Ajastult ajastule. Tallinn: Valgus.

EMS IV = Eesti murrete sõnaraamat IV. Toim. A. Haak jt. Tallinn: Eesti Keele Instituut 2004-2008.

Heinonen-Rivasto, Reija-Tuulia 2000. Druiidide puuhoroskoop. Tallinn: Sinisukk.

Hiiemäe, Mall 1982. Külvinädalad eesti rahvatraditsioonis. - Läänemeresoomlaste etnokultuuri küsimusi. Eesti NSV Etnograafiamuuseum. Tallinn: Valgus, lk 106-109.

Hiiemäe, Mall 1989. Eestlaste külviaegadest. - Paar sammukest eesti kirjanduse uurimise teed. Uurimusi XII Jakob Hurda 150. sünniaastapäevaks. Eesti NSV Teaduste Akadeemia F. R. Kreutzwaldi nimeline Kirjandusmuuseum. Tallinn: Eesti Raamat, lk 158-176.

Houghton, Marlene 2009. Astroloogiline apteek. Sinu sodiaagimärgi teejuht täiusliku tervise juurde. Tallinn: Ersen.

Jaagosild, Endla 1976. Viljakoristustöödega seotud traditsioone ja kombeid Eestis. - Etnograafiamuuseumi aastaraamat XXIX. Toim. A. Voolma. Tallinn: Valgus, lk 29-46.

Jürgenson, Aivar 2005. Seened kultuuriloos. Tallinn: Argo.

Kuresoo jt 2001 = Kuresoo, Rein; Hendrik Relve; Indrek Rohtmets (koost.). Eesti elusloodus. Tallinn: Varrak 2001.

Kuperjanov, Andres 2003. Eesti taevas. Uskumusi ja tõlgendusi. Tartu: Eesti Folkloori Instituut.

Kõiva, Mare (2006). Rahuldava kultuuri loomine. Arheoastronoomia arengujooned nõukogude ajal. - Mäetagused, nr 30, lk 59-84.

Kõiva, Mare s.a. (koost.). Rehepapp ehk rahvausundi ja muistendite andmebaas. http://www.folklore.ee/rehepapp/. [Viimane külastus 21.03.2010.]

Kütt jt 2007 = Kütt, Auli; Ahto Kaasik; Kristiina Zadin (koost.). Maavalla kalender 10220 (2007). 
Lintrop, Aado s.a. (koost.). Maailm, taevas ja taevakehad. Rahvaastronoomiat Eesti Rahvaluule Arhiivi uskumuste ja kombekirjelduste (uk) kartoteegist. http:// www.folklore.ee/ aado/maailm/. [Viimane külastus 21.03.2010.]

Loorits, Oskar 2000. Liivi rahva usund. IV-V. Tartu: Eesti Kirjandusmuuseum.

Malm, Ragna (koost.) 2004. Ilu astroloogia. Enda ja oma saatust muuta on võimalik. Tallinn: Odamees.

Merimaa, Mercedes 2010. Minu tee taimede väeni. Tallinn: Menu kirjastus.

Muir, Ada 2003. Päikesemärkide ravimtaimed ja tervisetoidud. Sissejuhatava osa ravimtaimede kasutamise kohta on kirjutanud Jude C. Williams. Tallinn: Sinisukk.

Paatsi, Kristi; ja Vello Paatsi 2008. Kalender eestlase ajalooalase maailmapildi kujundajana 19. sajandi algusest 1905. aastani. - Oskar Kallase päevXXII eesti raamatuteaduse konverentsi teesid. Koost. M. Kiipus. Tartu: Eesti Kirjandusmuuseum, lk 9-12.

Peil, Madis 1993. Eesti taimenimetuste arvutiregister VILBASTE. Versioon 2.1 ECOLINK.

Plath, Ulrike 2010. Kommunikation als Drahtseilakt: Verwalter auf dem baltischen Gutshof in der Frühen Neuzeit. -Das Leben auf dem Lande im Baltikum. Ed. J. Heyde. Lüneburg: Carl-Schirren-Gesellschaft [ilmumas].

Pärdi, Heiki 2008. Argielu üleminek agraarajastust moodsasse ühiskonda. - Eesti rahvakultuur. Koost. ja toim. A. Viires, E. Vunder. Tallinn: Eesti Entsüklopeediakirjastus, lk 479-497.

Raal, Ain 2007. Teekond taimede taha. Taimravi alternatiivsed harud. Tartu: Elmatar.

Scarlett, E. P. 1941. Paracelsus. Part II. - The Canadian Medical Association Journal, No. 44(6), pp. 618-621.

Silvano, E. 1933-1935. Arstimine kodumaal kasvavate taimedega okkultalusel. Vaimsuse Ideoloogia. Hingelise enesearenduse ja metapsühhika ajakiri. 1933, lk 13-14, 27; 1934, lk 13-14, 43, 68; 1935, lk 11-12, 27-28, 44-45, 60-61.

Suhonen, Pentti 1936. Suomalaiset kasvinnimet. Annales Botanici Societatis Zoologicae-Botanicae Finnicae Vanamo 7: 1. Helsinki: SKS.

Sõukand, Renata; Raivo Kalle (koost.) 2008. HERBA: Historistlik Eesti Rahvameditsiini Botaaniline Andmebaas. Võrguteavik. Tartu: EKM Teaduskirjastus. http://herba.folklore.ee.

Sõukand, Renata; Raivo Kalle 2010. Plant as object within herbal landscape: different kinds of perception. - Journal of Biosemiotics 3 (3). DOI 10.1007/ s12304-010-9078-9 [ilmumas].

Tammeorg jt 1984 = Tammeorg, Johannes; Oskar Kook; Gustav Vilbaste. Eesti NSV ravimtaimed. 5., täiendatud ja parandatud trükk. Tallinn:Valgus 1984.

Vahtre, Lauri 2000. Eestlase aeg. Uurimus Eesti rahvapärase ajaarvamise ajaloost. Teine täiendatud ja parandatud trükk. Tallinn: Varrak.

Viires, Ants 2000. Puud ja inimesed. Teine trükk. Tartu: Ilmamaa.

Vilbaste, Gustav 1993. Eesti taimenimetused = Nomina vernacula plantarum Estoniae. Eesti Teaduste Akadeemia Emakeele Seltsi toimetised 20 (67). Tallinn: Emakeele Selts. 
Watts, Sheldon 2003. Disease and Medicine in World History. London: Routledge.

Öpik, Elina 1981. Mõni sõna külvinädalatest, odrast ja ennemuistsest ajaarvamisest. - Eesti ajaloo probleeme. Eesti NSVTeaduste Akadeemia korrespondentliikme Artur Vassara 70. sünniaastapäevale pühendatud teaduskonverentsi ettekannete teesid, Tallinn, 18. nov. 1981. Tallinn: Eesti NSV Teaduste Akadeemia, lk 192-201.

\section{Summary}

\section{ASTRAL BODIES IN ESTONIAN PLANT FOLKLORE}

The current article analyzes the association of astral bodies with plant names, the reflection of astral bodies and astrology in plant medicine, the suggested influence of astral bodies to farming and crop growing in past and nowadays.

Of angiosperms the plants with five or more petals of different colour have got their name after stars for Estonians as well as for the Finnish. Only one plant, Melampyrum nemorosum, has been connected with moonlight by the Estonians, for the Finnish the round mushroom from the genus of Bovista shares the same lore. A more noteworthy difference can be followed in case of plants named after the sun: the Estonians have three, the Finnish seven species and two genii of plants with white and yellow petals that have been named after the sun. For the Estonians only mushrooms have been associated with the sky: the russula and primitive fungi that cannot be determined more exactly, the so-called pieces of clouds, the Finnish have popular plant names with taevas(sky)-prefix for the Nottingham catchfly (Silene nutans), ground-ivy (Glechoma hederacea), corn. The plant names with the affixes of täht (star), kuu (moon) and päike (sun), designated after the Latin name are common for both in the Estonian as well as the Finnish language, but the Finnish cosmology of plant names is considerably more diverse.

The most important astral body which the Estonians and Livonians used to arrange their activities after, was the moon. Similarly to their predecessors the authors did not try to find regularity in the activities on the basis of the material, since the data concerning the acknowledgement of the position of the moon is very contradictory. The common aspect for the Estonians and the Livonians is the sowing and planting of plants which grow downwards during the old moon, and of the plants which grow upwards during the new moon. The confusion might have brought along by the sowing calendars that started to be issued since the 18th century where erroneous data about the moon was often published. The sowing calendars 
are nowadays widely distributed in both the written word as well as the internet but they still confuse their users.

Only one astral body - the moon - was reflected in the older Estonian folklore of plant medicine. The moon was associated with power possessing species like rowan and alder. The West-European medieval astroherbalism retreated there by the beginning of the 18th century and it probably remained unfamiliar to Estonians at the time. It reached the Estonian written texts only in the 1930ies and again since the final decades of the 20 th century and has now occupied the so far unfilled niche in literature. Although the principles of astroherbalism are complicated, it does have a small circle of followers.

The scarce connection of ethnoastronomy and -astrology with plant use allows concluding that in case of plant folklore as practical and important knowledge with regard to survival, predominantly traditional understandings guided and all new was accepted cautiously and selectively, chaotically integrating it with the old system. Only since the end of the 20th century when the broken tradition and the mass distribution of astroherbalism and sowing calendars collided, an opportunity arose for the wider spread of the latter phenomena to folklore.

KEY WORDS: ethnobotany, ethnoastronomy, plant names, astroherbalism, sowing calendars, astral bodies 